\title{
KEBERAGAMAN ELEMEN BUDAYA DALAM PEMBELAJARAN PENDIDIKAN AGAMA ISLAM DI SEKOLAH DASAR ISLAM DI MALANG
}

\author{
Triyo Supriyatno
}

Fakultas Ilmu Tarbiyah dan Keguruan UIN Maulana Malik Ibrahim Malang

Email: Trios70@yahoo.com

\begin{abstract}
The education system in Indonesia requires multicultural education model for Indonesian society which has cultural diversity. The Government has made efforts in disseminating the concept of multicultural education before applying it as a representative model relevant for every level of education, but it still needs condition of situational diversity in the reality of people's life in order to be the spearhead of success in education. The case study implemented qualitative approach and its participants were PAI teacher selected through purposive sampling. The result of in-depth interviews, classroom observation and documentation were analyzed using qualitative description. The findings show the application of elements of various cultures in the teaching of PAI which has been identified as a mechanism to develop relationship, to confirm the universality of Islam, dakwah method and the requirements of curriculum. It also reveals some existing obstacles in implementing these elements, namely the constraints of teachers, lack of reading and less training. Although this study showed that PAI teachers in this study attempted to implement various cultural elements in their teaching, the level of implementation of these elements is still at an acceptable level. Hence, the PAI teachers must enhance their understanding, knowledge, skills, and expertise to improve and develop their skills in applying the elements of multicultural education in the learning of PAI .
\end{abstract}

Sistem pendidikan di Indonesia membutuhkan model pendidikan multikultural untuk masyarakat Indonesia yang memiliki keragaman budaya. Pemerintah telah melakukan upaya mensosialisasikan konsep pendidikan multikultural sebelum diterapkan sebagai representasi model yang relevan pada setiap tingkat pendidikan, tetapi masih perlu kondisi keragaman situasi dalam realitas kehidupan 
masyarakat agar menjadi ujung tombak keberhasilan pendidikan. Studi kasus ini menerapkan pendekatan kualitatif dan informannya guru PAI dengan sampel bertujuan (purposive sampling). Hasil wawancara mendalam, observasi kelas dan dokumentasi dianalisis dengan menggunakan deskriptif kualitatif. Temuan menunjukkan bahwa penerapan unsur-unsur berbagai budaya dalam pengajaran PAI telah diidentifikasi sebagai mekanisme pengembangan hubungan, untuk mengkonfirmasi universalitas Islam, metode dakwah dan persyaratan kurikulum. Hasil penelitian juga mengungkapkan beberapa kendala dalam melaksanakan elemen-elemen ini, yaitu kendala guru, kurangnya membaca dan kurang pelatihan. Meskipun studi ini menunjukkan bahwa guru PAI berusaha untuk melaksanakan berbagai unsur budaya dalam mengajarnya, tingkat pelaksanaan elemen ini masih berterima. Oleh karena itu, guru PAI harus meningkatkan pemahaman, pengetahuan, keterampilan, dan keahlian untuk meningkatkan dan mengembangkan keterampilan guru dalam menerapkan unsur-unsur pendidikan multikultural dalam pembelajaran PAI.

Keywords: multicultural education, religious Islamic education, archipelago

\section{Pendahuluan}

Indonesia adalah negara yang memiliki kurang lebih 13.000 pulau, dengan jumlah penduduk kurang lebih 210 juta jiwa serta mempunyai 300 suku yang menggunakan hampir 200 bahasa yang beragam. Selain itu, di Indonesia juga ada penganut agama dan kepercayaan yang beragam seperti Islam, Katholik, Protestan, Hindu, Budha, Konghucu, serta berbagai macam kepercayaan. Keragaman ini dapat memunculkan kebudayaan (culture) yang berbeda-beda sehingga Indonesia termasuk salah satu Negara multikultural terbesar di dunia (Kosim, 2009: 150). Dari keberagaman ini maka Indonesia memiliki sebuah motto Bhinneka Tunggal Ika yang artinya beragam namun menyatu dalam satu ikatan.

Keberagaman dan perbedaan budaya dapat menjadi suatu anugerah dan menjadi kekayaan bangsa Indonesia yang amat tinggi nilainya, membuat kehidupan masyarakat itu dinamis, penuh warna, tidak stagnan, dan membuat antara yang satu dengan lainnya saling melengkapi dan saling membutuhkan. Oleh karena itu, pluralitas dapat memperkaya kehidupan dan menjadi esensi kehidupan masyarakat di Indonesia. Akan tetapi, hal tersebut juga rentan terhadap konflik sosial yang akan menjadi ancaman integrasi bangsa yang diwarnai dengan adanya permusuhan dan konflik antar agama, kebencian terhadap budaya lain, hingga memacu terjadinya peperangan. Berbagai kasus dan peristiwa yang berbau SARA (suku, agama, ras, dan antar golongan) sering terjadi di negeri ini, diantaranya kasus penistaan agama, perkelahian antar 
golongan, suku, ras dan lain-lain.

Maka pendidikan yang berbasis pada keberagaman elemen budaya (multikultural) dapat menjadi salah satu alternatif solusi yang tidak dapat dihindari. Pendidikan multikultural merupakan pendidikan yang memberikan peluang sama pada seluruh anak bangsa tanpa membedakan perlakuan karena keberagaman etnik, budaya, dan agama serta menghendaki penghormatan dan penghargaan manusia setinggi-tingginya terhadap harkat dan martabat manusia dari manapun latar belakang budayanya. Dalam konteks Indonesia yang sarat dengan kemajemukan, pendidikan ini memiliki peran sangat strategis untuk dapat mengelola kemajemukan tersebut secara kreatif. Solusinya adalah dengan melalui implementasi pendidikan multikultural di sekolah, atau madrasah ataupun pondok pesantren.

Dalam Undang-Undang RI No. 20 Tahun 2003 tentang Sistem Pendidikan Nasional, Pasal 1 ayat 1 yang menyatakan bahwa pendidikan adalah usaha sadar dan terencana untuk mewujudkan suasana belajar dan proses pembelajaran agar peserta didik secara aktif mengembangkan potensi dirinya untuk memiliki kekuatan spiritual keagamaan, pengendalian diri, kepribadian, kecerdasan, akhlak mulia, serta keterampilan yang diperlukan dirinya, masyarakat, bangsa, dan negara (Depdiknas, 2003: 65). Dari makna tersebut pendidikan merupakan salah satu media yang efektif untuk melahirkan generasi yang punya pandangan tentang keragaman tersebut sabagai bagian yang harus diapresiasi secara konstruktif. Pemahaman dan kesadaran terhadap realitas yang multikultural lewat jalur pendidikan dalam semua jenjang pendidikan tentu akan memiliki dampak yang konkret dalam kehidupan secara luas di masa depan. Untuk itu pendidikan multikultural sangatlah penting dan vital untuk diterapkan di sekolah-sekolah.

Bila melihat kondisi bangsa yang mayoritas penduduknya adalah muslim, konsep pendidikan multikultural saja rasanya belumlah cukup untuk menjawab permasalahan-permasalahan di atas. Oleh karena itu, diperlukan peran serta aktif lembaga pendidikan Islam. Namun permasalahan yang mendasar dalam hal ini adalah sejauh mana orientasi pendidikan Islam dalam mengakomodir permasalahan-permasalahan tersebut. Untuk itu diperlukan model keberagaman elemen budaya dalam pembelajaran pendidikan agama Islam (PAI) di sekolah.

Pendidikan agama Islam adalah upaya sadar dan terencana dalam menyiapkan peserta didik untuk mengenal, memahami, menghayati, hingga mengimani ajaran agama Islam, dibarengi dengan tuntunan untuk menghormati penganut 
agama lain dalam hubungannya dengan kerukunan antar umat beragama hingga terwujudnya kesatuan dan persatuan bangsa. Untuk menumbuhkan sikap tersebut pendidikanlah yang paling tepat, utamanya pendidikan agama Islam untuk dijadikan wadah menyemai benih toleransi, harmoni kehidupan dan penghargaan yang tulus atas realitas keragaman kultural-religius masyarakat. Sebab pendidikan Islam yang menjadi subsistem pendidikan nasional menjadi salah satu media yang paling efektif untuk melahirkan generasi yang memiliki pandangan yang mampu menjadikan keragaman sebagai bagian yang harus diapresiasi secara konstruktif (Naim dkk., 2008: 33). Selain itu, pendidikan agama Islam mampu memberi penyadaran (consciousness) kepada masyarakat bahwa konflik bukan sesuatu hal yang baik untuk dibudayakan dan mampu memberi solusi yang mencerdaskan, antara lain dengan cara mendesain bahan ajar, motode, hingga kurikulum yang memberi ruang penyadaran kepada masyarakat akan pentingnya sikap saling toleran, menghormati perbedaan suku, agama, ras, etnis dan budaya masyarakat Indonesia yang multikultural (Mahfud, 2010: 5).

Hal tersebut memunculkan sebuah kegelisahan akademik tersendiri bagi peneliti, ditambah lagi dengan munculnya kontradiksi atau paradoks antara intensitas dialog antar komunitas (agama) namun benih konflik tumbuh dimana-mana, serta adanya fenomena baru kekerasan atas nama agama (Islam) dengan melibatkan generasi anak-anak usia dini (usia SD/MI) untuk dijadikan eksekutor antarsesama tanpa empati dan simpati kemanusiaan sedikitpun.

Kajian dalam tulisan ini diarahkan untuk mengelaborasi apakah pendidikan agama Islam di SD Islam telah memberi ruang untuk tumbuhnya perilaku toleransi bagi para siswa ataukah sebaliknya justru terjadi penyempitan dan penutupan lingkup kajian itu dengan menggunakan model prejudaise dan menanamkan elemen-elemen budaya eksklusifisme atau kebencian terselubung dalam memaknai sebuah realitas keragaman serta memunculkan konsekuensi logis dari pola pembelajaran tersebut.

\section{Metode Penelitian}

Penelitian ini merupakan penelitian kualitatif dengan mengambil latar belakang SD Islam Surya Buana Malang. Pengumpulan data dilakukan dengan observasi, wawancara, dan dokumentasi. Analisis data dilakukan dengan menggunakan model Miles dan Huberman, yaitu reduksi data, display data, dan penarikan kesimpulan. Apabila kesimpulan yang dikemukakan pada tahap awal, didukung oleh bukti-bukti yang valid dan konsisten saat peneliti kembali ke lapangan mengumpulkan data, maka kesimpulan yang 
dikemukakan merupakan kesimpulan yang kredibel. Pemeriksaan keabsahan data yang digunakan dalam penelitian ini adalah triangulasi.

\section{Metodologi Dakwah}

Menurut Fakhri, Mamik dan Djalil, kebutuhan tentang metodologi dakwah dalam penerapan elemen-elemen pelbagai budaya ini merupakan salah satu dari tuntutan agama. Sebagai seorang da'i, guru seharusnya faham cara memahami seseorang karena itu merupakan tuntutan agama Islam. Menurut mereka:

"...kalau saya jawab dalam bahasa daerah, mungkin siswa mudah untuk mengingat yang saya ajarkan, tapi sejujurnya... saya akan jawab sesuai tuntutan agama Islam. Sebagai seorang da'i, sepatutnya dan seharusnya kita sebagai pendidik memahami bahwa itu sebagian dari tuntutan agama Islam dan juga satu cabang dari ajaran Islam..." (Fakhri, Mamik dan Djalil, wawancara: 15 April 2016). Djalil menambahkan bahwa dakwah merupakan salah satu daripada tuntutan agama Islam maka beliau berpendapat tujuannya kepada penerapan elemen ini nanti akan juga memuliakan Islam itu sendiri. Ini dinyatakan oleh beliau melalui pernyataan berikut:

"tujuannya untuk memuliakan Islam, saya kira ini satu hal yang perlu kita tekankan dan perhatikan dengan seksama. Itu lah esensi dari ajaran Islam..." (Djalil, wawancara: 15 April 2016)

\section{Hasil Penelitian}

\section{Universalitas Islam}

Mamik menyatakan bahwa agama Islam merupakan agama yang bersifat universal karena ajaran Islam sesuai untuk diamalkan oleh siapa saja dan di mana saja. Ajaran Islam senantiasa mengajarkan umatnya untuk selalu berbuat baik kepada siapa saja termasuk kepada orang di luar Islam dan lebih-lebih lagi kepada yang baru memeluk Islam. Dengan memberikan teladan dalam kehidupan mereka ketika belum memeluk Islam yang tidak bertentangan dengan Islam akan dapat menggambarkan bahwa ajaran Islam adalah universal. Ini dijelaskan oleh beliau melalui pernyataan wawancara berikut:

"walaupun seseorang baru masuk Islam, yang mungkin dalam kehidupan sebelumnya banyak hal-hal yang baik, maka Islam juga menyatakan kebaikan yang sama. Maka, Islam ini universal” (Mamik, wawancara: 15 April 2016).

Hal ini juga memudahkan bagi integrasi antar etnis dan suku yang menunjukkan bahwa ajaran itu sendiri begitu komprehensif. Ini dinyatakan oleh DJalil melalui wawancara berikut: 
"Islam ialah senantiasa berbuat baik walaupun terhadap orang bukan Islam dan faktor agama Islam ini lah yang memudahkan bagi integrasi antara etnis dan suku..." (Djalil, wawancara: 15 April 2016).

\section{Persyaratan Kurikulum}

Konsep integrasi yang ditekankan dalam sistem pendidikan, seperti penglibatan siswa dalam aktivitas ekstrakurikuler misalnya merupakan salah satu daripada cara memupuk semangat integrasi dalam kalangan siswa di sekolah. Oleh karena itu, pihak sekolah mengambil langkah untuk melibatkan semua siswa yang memiliki latar belakang yang berbeda dalam semua aktivitas kegiatan ekstrakurikuler. Sehingga pihak yayasan tidak membenarkan sama sekali jika dalam satu jenis kegiatan ekstrakurikuler dimonopoli oleh satu etnis atau suku saja.

"Sebab itu para siswa kami pun harus mau terlibat, kalau tidak, pembinaan persatuan yang sekian lama ditumbuhkan akan luntur, jangankan satu etnis atau suku saja, bahkan adanya pembaharuan tentang integrasi dalam kurikulum secara konsep dan aplikasi”(Mamik, wawancara: 15 April 2016)

Namun Djalil memberi pandangan yang sedikit berbeda, menurut beliau:

“...kalau pendidikan sendiri tidak melihat perkara ini adalah satu keharusan, mungkin dia boleh dipisahkan dari sekolah ini, dengan tidak adanya percampuran, etnis, bahasa daerah, (Djalil, wawancara: 15 April 2016)

Dalam pandangan para pendiri dan para guru di sekolah dasar Islam Surya Buana di Malang bahwa semua warga sekolah terutamanya para pendidik di kelas adalah para da'i yang melakukan transfer ilmu pengetahuan, nilai, dan ketrampilan dalam rangka membentuk peserta didik agar menjadi anak yang beriman dan bertakwa, serta beramal shaleh dalam kehidupannya sehari-hari (Djalil, wawancara: 15 April 2016).

Keragaman etnis adalah kenyataan yang harus diterima oleh umat manusia. Adanya pluralitas suku, tentunya tidak harus membuat umat manusia yang berasal dari etnis dan ras yang berbeda menjadi terpecah belah dan saling memusuhi. Meskipun dalam sejarah umat manusia ada banyak kisah sedih yang memilukan yang diakibatkan oleh adanya pertentangan antar ras dan etnis. Multikultural berjalan bergandengan tangan dengan proses demokratisasi di dalam kehidupan bermasyarakat. Proses demokratisasi tersebut dipicu oleh pengakuan terhadap hak asasi manusia yang tidak membedakan perbedaanperbedaan manusia atas warna kulit, agama dan gender. Manusia diciptakan 
oleh Allah dengan martabat yang sama tanpa membedakan warna kulit, asalusul, agama dan jenis kelamin (Djalil, wawancara: 15 April 2016). Pendidikan multikultural merupakan sikap "peduli" dan mau memahami atau disebut dengan "politics of recognition" politik pengakuan terhadap orang-orang dari kelompok minoritas (Ibrahim, 2013: 129).

Dalam proses belajar mengajar, di sekolah tersebut sangat mengutamakan kebersamaan, walaupun dari latar belakang yang berbeda-beda, baik dari guru maupun siswa, mereka tidak canggung untuk berbagi cerita, berbagi pengalaman, berbagi ilmu dan sebagainya, melihat adanya toleransi yang sedemikian tingginya dan internalisasi nilai-nilai agama yang baik, tidak heran jika antar guru maupun antar siswa yang berbeda latar belakang tersebut sangat rukun dan bisa berjalan beriringan sehingga tercipta susana belajar yang kondusif, menyenangkan dan kekeluargaan yang tinggi (Djalil, wawancara: 15 April 2016).

Berkaitan dengan pembelajaran PAI, sekolah tersebut tetap mengikuti kurikulum yang ditetapkan oleh Dinas Pendidikan Kota Malang, mata pelajaran PAI yang ada meliputi al Quran, Akidah Akhlak, Fiqh, Tarikh, kebudayan Islam dan Praktek Pengamalan Ibadah. Pembelajaran pendidikan agama Islam berbasis multikultural adalah salah satu model pembelajaran pendidikan agama Islam yang dikaitkan pada keragaman yang ada, baik itu keragaman agama, etnis, bahasa maupun nilai-nilai kultural sebagai dasar pembelajaran di lembaga tersebut. Hal ini dilakukan karena dalam satu sekolah terdiri dari berbagai siswa yang cukup beragam, agar tidak terjadi konflik di dalamnya sangat penting pembelajaran pendidikan agama Islam berbasis multikultural dalam membina toleransi umat manusia di kalangan siswa diterapkan (Djalil, wawancara: 15 April 2016).

Sebagai contoh pembelajaran PAI berbasis multikultural, ketika pembelajaran al Quran berlangsung, guru menerangkan kepada siswa dalam proses pembelajarannya yaitu menekankan kepada para siswanya agar tidak menjelek-jelekan atau membanding-bandingkan kitab-kitab agama lain dengan membenarkan atau mengiyakan kitab Agama Islam. Karena bisa kita ketahui bersama bahwasanya sebelum kitab agama Islam (al Quran) ada kitab-kitab agama lain yang sudah terlebih dahulu ada, maka dari itu sebagai umat Islam wajib menghormati kitab-kitab terdahulu (hasil observasi).

Selain itu, SDI Surya buana juga menerapkan sebuah metode pembelajaran 
bagi para siswanya yang dikenal dengan model tripel R. Model ini diterapkan dengan pemanfaatan hubungan huruf " $R$ " yang terdiri dari Reasoning, Research dan Religius, sebagaimana gambar di bawah ini (dokumentasi, h. 45).

Gambar 1. Hubungan Triple R

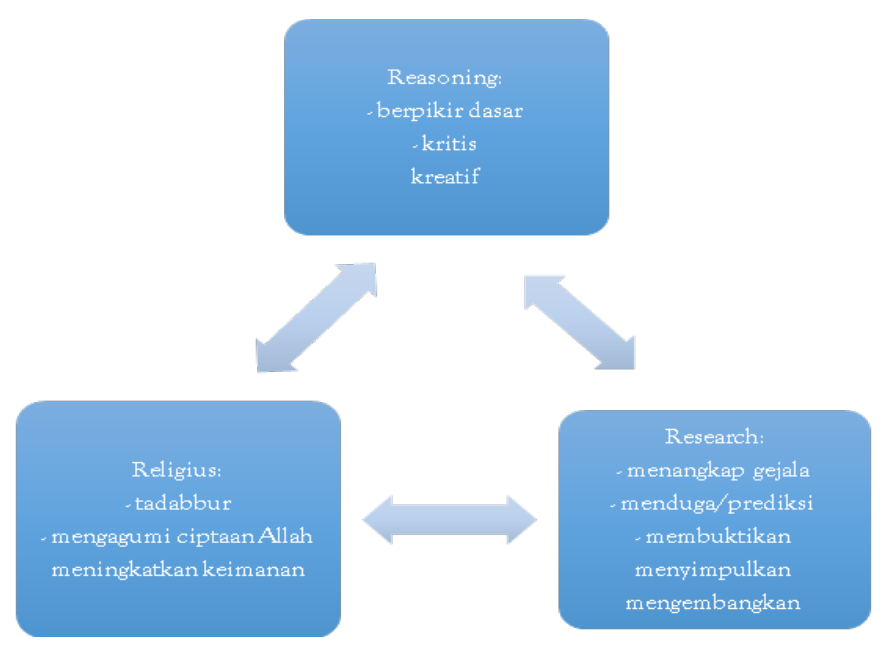

Sumber: Buku Lembaga Pendidikan Formal (Surya Buana, 2012: 45)

Dengan kerangka hubungan triple $\mathrm{R}$ tersebut diharapkan para siswa memiliki kebiasaan dan budaya berpikir, meneliti, dan keagamaan, dalam setiap mempelajari semua mata pelajaran yang diajarkan atau dibimbing oleh gurunya di kelas masing-masing (Djalil, wawancara: 15 April 2016).

Dari model hubungan triple $\mathrm{R}$ ini pula diharapkan pola interaksi guru dan peserta didik senantiasa memperhatikan keuniversalan ajaran Islam dalam mengembangkan keberagaman potensi yang dimiliki peserta didik, memanfaatkan metode dakwah bil lisan dan bil hal serta sesuai dengan sistem kurikulum yang ada di sekolah yaitu full day school (Djalil, wawancara: 15 April 2016).

\section{Pembahasan}

Konflik dapat disebabkan dari masalah yang sederhana sampai pada masalah yang kompleks. Konflik yang terjadi di beberapa wilayah Indonesia sudah sampai pada tahap yang mengkuatirkan, hal ini ditandai dengan adanya beberapa kelompok masyarakat yang menggunakan konflik sebagai bentuk ekspresi untuk menumpahkan segala kekesalan dan kekecewaan yang mereka 
rasakan, dan kelompok masyarakat lainnya yang menggunakan konflik sebagai alat untuk menyelesaikan persoalan (Somantrie, 2011: 660-672). Pendidikan multikultural diharapkan bisa menjadi suatu bentuk proses transformasional, bukan hanya proses toleransi. Pendidikan multikultural bukan sekedar mengajar tentang kebudayaan yang berbeda-beda, kebudayaan dari berbagai kelompok etnik dan keagamaan dan mendukung apresiasi, kenyamanan, toleransi tehadap budaya lain (Rosyada, 2014: 1-12). Multikulturalisme menjadi semacam respons kebijakan baru terhadap keragaman. Dengan kata lain, adanya komunitas-komunitas yang berbeda saja tidak cukup; sebab yang terpenting adalah bahwa komunitas-komunitas itu diperlakukan sama oleh negara. Oleh karena itu, multikulturalisme sebagai sebuah gerakan menuntut pengakuan (politics of recognition) terhadap semua perbedaan sebagai entitas dalam masyarakat yang harus diterima, dihargai, dilindungi serta dijamin eksistensinya. Dalam pengertian yang lebih jelas, multikulturalisme dijelaskan dengan pengakuan yang sama atau kesederajatan atas keberbagaian, baik dalam hal agama, suku atau budaya.

Pendidikan multikultural sejatinya merupakan pendidikan yang menjunjung tinggi persamaan hak dan martabat manusia. Sebagai perspektif yang mengakui realitas politik, sosial dan ekonomi yang dialami oleh masingmasing individu dalam pertemuan manusia yang kompleks dan beragam secara kultur, dan merefleksikan pentingnya budaya, ras, gender, etnisitas, agama, status sosial, ekonomi, dan pengecualian-pengecualian dalam proses pendidikan (Mahfud, 2010:5). Selain itu pendidikan multikultural sebagai upaya untuk melatih dan mengembangkan karakter siswa agar mampu bersikap demokratis, humanis dan pluralis dalam lingkungan mereka. Dalam agama Islam konsep pendidikan multikultural ini berdasar dari kenyataan bahwa manusia diciptakan Tuhan dengan berbeda-beda, baik dari jenis kelamin, suku bangsa, warna kulit, budaya dan sebagainya. Namun perlu diingat bahwa yang mulia di sisi Tuhan adalah yang paling baik amal perbuatannya/bertakwa (Q.S. Al-Hujurat (49):13). Pendidikan multikultural sebagai instrumen rekayasa sosial mendorong sekolah agar dapat berperan dalam menanamkan kesadaran dalam masyarakat multikultur dan mengembangkan sikap tenggang rasa dan toleran utuk mewujudkan kebutuhan serta kemampuan bekerjasama dengan segala perbedaan yang ada (Hidayatulloah Al Arifin, 2012: 72).

Dalam kajian Banks yang dikutip Agus Iswanto, bahwa dalam implementasi pendidikan multikultural terdapat lima dimensi yang harus ada yaitu, pertama, adanya integrasi pendidikan dalam kurikulum (content integration) yang di dalamnya 
melibatkan keragaman dalam satu kultur pendidikan yang tujuan utamanya adalah menghapus prasangka. Dengan adanya faktor keagamaan, maka semua mata pelajaran yang diajarkan akan memiliki nilai-nilai keagamaan berupa akhlak, karakter ataupun budi pekerti. Kedua, konstruksi ilmu pengetahuan (knowledge construction) yang diwujudkan dengan mengetahui dan memahami secara komprehensif keragaman yang ada. Dengan konstruksi berpikir dan meneliti yang ada pada $3 \mathrm{R}$, maka siswa dilatih oleh gurunya dalam setiap mata pelajaran yang diterimanya. Ketiga, pengurangan prasangka (prejudice reduction) yang lahir dari interaksi antar keragaman dalam kultur pendidikan. Dengan adanya hubungan triple R di sekolah dasar Islam Surya Buana, maka pengurangan prasangka dapat diminimalisir karena guru telah melakukan aktifitas 3R dalam setiap pelajaran yang diajarkan kepada siswanya. Keempat, pedagogik kesetaraan manusia (equity pedagogy) yang memberi ruang dan kesempatan yang sama kepada setiap elemen yang beragam. Dengan adanya elemen berpikir dari tingkat dasar hingga kritis dan kretif, maka para siswa di SD Islam Surya Bana memiliki kemampuan yang sama dalam menyikapi keragaman yang ada di dalam kelasnya. Kelima, pemberdayaan kebudayaan sekolah (empowering school culture). Elemen budaya meneliti diharapkan dapat menumbuhkembangkan potensi siswa yang pada akhirnya dapat memberdayakan kebudayaan sekolah secara menyeluruh.

Selain itu, dalam membentuk perilaku toleran akan tetap memberikan penilaian, baik positif maupun negatif, terhadap pendapat orang lain dengan komitmen moral dan kesadaran menghormatinya. Oleh sebab itu bertoleransi bukan berarti bersikap acuh tak acuh, akan tetapi memberikan kritik secara sopan, dan empatik dalam berdialog. Setiap orang harus menghormati perbedaan sebagaimana juga harus secara kritis mengoreksi pemahaman sendiri dan orang lain dalam proses mencari pemahaman yang lebih baik. Konsep ini disebut dengan "toleransi kritis" (critical toleration) yang berdiri diatas prinsip "interaksi kritis" (Masduqi, 2011: 22). Kerangka berperilaku itu akan dapat terwujud bila dalam pembelajaran menggunakan model triple $\mathrm{R}$ seperti yang telah diimplementasikan di sekolah dasar Islam Surya Buana Malang. Berperilaku yang toleran berasal dari berpikir yang toleran, dan sudah sepatutnya dimulai sejak dini di jenjang pendidikan sekolah dasar. Hal yang sama juga telah dilakukan penelitian oleh Weni (Weni, 2014: 1) dan Farida yang juga berusaha mengajarkan pendidikan multicultural pada sisswa sekolah (Farida, 2010: 89). 
Sikap toleran ini tentunya dipengaruhi juga oleh kematangan dalam mengelola emosi diri sendiri. Toleransi dalam tradisi Islam nampak sejalan dengan filsafat Stoicisme yang menitikberatkan pada pentingnya mengontrol emosi ketika menghadapi suatu perbedaan. Diakui atau tidak, salah satu kehidupan yang memiliki konstribusi untuk kuatnya atau lemahnya pemahaman multikulturalisme adalah pendidikan di sekolah. Sekolah sebenarnya menyediakan ruang dimungkinkannya memperkuat basis pengetahuan dan pengalaman hidup siswa menghargai perbedaan dan kemajemukan (Cholil, 2008: 29).

\section{Simpulan}

Penerapan unsur-unsur berbagai budaya dalam pengajaran PAI telah diidentifikasi sebagai mekanisme untuk mengembangkan hubungan, untuk mengkonfirmasi universalitas Islam, metodologi dakwah dan persyaratan kurikulum. Selain itu, ada beberapa kendala yang ada dalam melaksanakan elemen-elemen ini, yaitu kendala guru, kurangnya membaca dan kurang pelatihan. Dalam implementasinya, guru PAI berusaha untuk melaksanakan berbagai unsur budaya dalam mengajarnya, tingkat pelaksanaan elemen ini masih pada tingkat yang dapat diterima. Oleh karena itu, guru PAI harus meningkatkan pemahaman, pengetahuan, keterampilan, dan keahlian untuk meningkatkan dan mengembangkan keterampilan guru dalam menerapkan unsur-unsur pendidikan multikultural dalam pembelajaran PAI.

\section{Daftar Pustaka}

Cholil, Suhadi (editor). 2008. Resonansi Dialog Agama dan Budaya: Dari Kebebasan Beragama Pendidikan Multikultural sampai RUU Anti Pornografi. Yogyakarta: Center for Religius \& Cross-Studies (CRCS).

Depdiknas. 2003. Undang-Undang Republik Indonesia No. 20 Tahun 2003 tentang Sistem Pendidikan Nasional. Jakarta: Pusat Data dan Informasi Pendidikan.

Farida Hanum dan Sisca Rahmadonna. 2010. Implementasi Model Pembelajaran Multikultural Di Sekolah Dasar Propinsi Daerah Istimewa Yogyakarta. Jurnal Penelitian Ilmu Pendidikan. Vol. 3, No. 1: 89-102. 
Hidayatullah Al Arifin, Akhmad. 2012. Implementasi Pendidikan Multikultural Dalam Praksis Pendidikan Di Indonesia. Jurnal Pembangunan Pendidikan: Fondasi dan Aplikasi. Vol. 1, No. 1: 72-82.

Ibrahim, Rustam. 2013. Pendidikan Multikultural: Pengertian, Prinsip, dan Relevansinya dengan Tujuan Pendidikan Islam. Jurnal Addin. Vol. 7, No. 1: 129-154.

Kosim, Muhammad. 2009. Sistem Pembelajaran Pendidikan Agama Islam Berwawasan Multikultural dalam Pendidikan Agama Islam dalam Perspektif Multikulturalisme. Jakarta: Balai LITBANG Agama.

Mahfud, Choirul. 2010. Pendidikan Multikultural. Yogyakarta: Pustaka Belajar.

Marpaung, Sayfri Fadillah. 2010. Pendidikan Multikultural Untuk Menata Kehidupan Bersama. Jurnal Saintikom. Vol. 8, No. 1: 1-8.

Masduqi, Irwan. 2011. Berislam Secara Toleran: Teologi Kerukunan Umat Beragama. Bandung: Mizan.

Naim, Ngainun \& Achmad Sauqi. 2008. Pendidikan Multikultural Konsep dan Aplikasi. Yogyakarta: Ar-Ruzz Media.

Rosyada, Dede. 2014. Pendidikan Multikultural Di Indonesia Sebuah Pandangan Konsepsional. Sosio Didaktika: Vol. 1, No. 1: 1-12.

Somantrie, Hermana. 2011. Konflik Dalam Perspektif Pendidikan Multikultural. Jurnal Pendidikan Dan Kebudayaan. Vol. 17, No. 6: 660-672.

Surya Buana. 2012. Lembaga Pendidikan Formal. Malang

Weni Wahyuandari, Desi Rahmawati. 2014. Pendidikan Multikultural (Studi Kasus Di Sekolah Lanjutan Tingkat Pertama (SLTP) Di Tulungagung. Jurnal Universitas Tulungagung Bonorowo. Vol. 2, No. 1: 1-15. 